\title{
Partial synthesis of serum carotenoids and their metabolites*
}

\author{
Frederick Khachik ${ }^{\bowtie}$ \\ Department of Chemistry and Biochemistry, University of Maryland, College Park, Maryland USA
}

\begin{abstract}
Human serum and tissues contain in excess of 12 dietary carotenoids and several metabolites that originate from consumption of fruits and vegetables. Among these are hydroxycarotenoids: $\left(3 R, 3^{\prime} R, 6^{\prime} R\right)$-lutein (1), (3R, $\left.3^{\prime} R\right)$ zeaxanthin (2), (3R,6 $\left.6^{\prime} R\right)$-a-cryptoxanthin (3), and (3R)$\beta$-cryptoxanthin (4). In addition, several dehydration products of 1 have also been identified in human serum, these are: $\left(3 R, 6^{\prime} R\right)-3$-hydroxy-3', $4^{\prime}$-didehydro- $\beta, \gamma$-carotene (5), $\left(3 R, 6^{\prime} R\right)$-3-hydroxy-2', $3^{\prime}$-didehydro- $\beta, \varepsilon$-carotene (6), and (3R)-3-hydroxy-3',4'-didehydro- $\beta, \beta$-carotene (7). Several metabolites of 1 and/or 2, namely, $\left(3 R, 3^{\prime} S, 6^{\prime} R\right)$-lutein (3'-epilutein, 8) and (3R,3'S;meso)-zeaxanthin (9) have also been characterized in human serum and ocular tissues. Semi-synthetic processes have been developed that separately transform commercially available 1 into 4 via 7 as well as 1 into 8 . While 8 is converted into 2 by base-catalyzed isomerization, 7 is transformed into 2 and its ( $3 R, 3^{\prime} S$;meso)-stereoisomer (9) by regioselective hydroboration.
\end{abstract}

Keywords: dietary hydroxycarotenoids, carotenoid metabolites, a-cryptoxanthin, $\beta$-cryptoxanthin, anhydroluteins, ionic hydrogenation, allylic deoxygenation, hydroboration

Received: 17 October, 2011; accepted: 01 March, 2012; available on-line: 17 March, 2012

\section{INTRODUCTION}

To date, 40-50 carotenoids have been identified in the extracts from commonly consumed foods; these can be classified as carotenoid epoxides, hydroxycarotenoids, hydrocarbon carotenoids, and carotenoid acyl esters (Khachik et al., 1991). Among these, hydroxycarotenoids and hydrocarbon carotenoids are absorbed by humans and are found in plasma, breast milk, and various organs and tissues whereas carotenoid epoxides have not been detected in humans (Khachik et al., 1992; 1997a; 2006). The major hydroxycarotenoids absorbed by humans are: $\left(3 R, 3^{\prime} R, \sigma^{\prime} R\right)$-lutein (1), (3R, $\left.3^{\prime} R\right)$-zeaxanthin (2), $\left(3 R, G^{\prime} R\right)$ - $\alpha$-cryptoxanthin (3), and (3R)- $\beta$-cryptoxanthin (4) and their $E / Z$-stereoisomers (Fig. 1). In addition, several hydroxycarotenoids that result from metabolic transformation of 1 have also been identified in human plasma. Among are: $\left(3 R, 6^{\prime} R\right)-3$-hydroxy-3', $4^{\prime}$-didehydro$\beta, \gamma$-carotene (5) (3R, $\left.\sigma^{\prime} R\right)-3$-hydroxy- $2^{\prime}, 3^{\prime}$-didehydro- $\beta, \varepsilon-$ carotene (6), and (3R)-3-hydroxy-3', $4^{\prime}$-didehydro- $\beta, \beta$ carotene (7) that are presumably formed by non-enzymatic acid-catalyzed dehydration of $\mathbf{1}$ (Khachik et al., 1995). Hydroxycarotenoids 1 and 2 appear to undergo extensive metabolism to several ketocarotenoids by a series of oxidation-reduction and double bond isomerization reactions. For example, $\left(3 R, 3^{\prime} S, 6^{\prime} R\right)$-lutein ( $3^{\prime}$-epilutein, 8) and (3R, $3^{\prime}$ S;meso)-zeaxanthin (9) are among the metabolites of 1 and/or 2 in human serum and ocular<smiles>CC1=C[C@@H](O)CC(C)(C)[C@H]1/C=C/C(C)=C/C=C/C(C)=C/C=C/C=C(C)/C=C/C=C(C)/C=C/C1=C(C)C[C@@H](O)CC1(C)C</smiles><smiles>CC(C)=C/C=C/C(C)=C/C=C/C(C)=C/C=C/C(C)=C/C=C/C=C(C)/C=C/C=C(C)/C=C/C1=C(C)CC(O)CC1(C)C</smiles>

$\left(3 R, 3^{\prime} R\right)$-Zeaxanthin (2)<smiles>CC1=CCCC(C)(C)C1/C=C/C(C)=C/C=C/C(C)=C/C=C/C=C(C)/C=C/C=C(C)/C=C/C1=C(C)C[C@@H](O)CC1(C)C</smiles>

$\left(3 R, 6^{\prime} R\right)-\alpha$-Cryptoxanthin (3)<smiles>CC1=C(/C=C/C(C)=C/C=C/C(C)=C/C=C/C=C(C)/C=C/C=C(C)/C=C/C2=C(C)C[C@@H](O)CC2(C)C)C(C)(C)CCC1</smiles>

(3R)- $\beta$-Cryptoxanthin (4)

Figure 1. Structures of dietary hydroxycarotenoids found in human plasma, breast milk and ocular tissues.

tissues that are formed by such reactions (Bone et al., 1993; Bernstein et al., 1997; Khachik et al., 1997b; Khachik et al., 2002). The structures of these carotenoid metabolites are shown in Fig. 2.

Epidemiological and experimental evidence to date suggest hydroxycarotenoids may protect against chronic diseases such as cancer (Van Poppel, 1993), cardiovascular disease (Morris et al., 1994) and age-related macular degeneration (AMD) (Seddon et al., 1994). Therefore, supplementation with these carotenoids in individuals with a low dietary intake of fruits and vegetables is essential. The lack of commercial availability of some of these non-vitamin A active dietary carotenoids has limited the investigation of their metabolism and their biological activity. With the exception of 1 and 2 , industrial production of hydroxycarotenoids 3-9 have not yet materialized. While the total synthesis of 1 and four of its stereoisomers has been reported (Khachik \& Chang, 2009), the isolation of this carotenoid from marigold flowers (Tagetes erecta) on industrial scale has proven to be the most viable and inexpensive route to this carotenoid (Khachik, 1995; Ausich \& Sanders, 1997). In addition, 1 with stereocenters at $3,3^{\prime}, 6^{\prime}$-positions serves as an excellent precursor in the partial synthesis of optically active hydroxycarotenoids with $\varepsilon$ - and $\beta$-end groups. An example of this is $\left(\sigma^{\prime} R\right)-\alpha$-carotene $(\mathbf{1 0})$ that could be ac-

e-mail: Khachik@umd.edu

*Presented at the 16th International Symposium on Carotenoids, 17-22 July, 2011, Kraków, Poland

Abbreviations: $\mathrm{BH}_{3}-\mathrm{THF}$, borane-tetrahydrofuran; $\mathrm{CH}_{3} \mathrm{l}$, methyl iodide; $\mathrm{NaBH}_{4}$, sodium borohydride. 
<smiles>C=C1C=C[C@H](C)[C]1/C=C/C(C)=C/C=C/C(C)=C/C=C/C=C(C)/C=C/C=C(C)/C=C/C1=C(C)CC(O)CC1(C)C</smiles>

$\left(3 R, 6^{\prime} R\right)-3$-Hydroxy-3',4'-didehydro- $\beta, \gamma$-carotene [Anhydrolutein I] (5)<smiles>CC1=CC=CC(C)(C)[C@@H]1/C=C/C=C(C)/C=C/C=C/C=C(C)/C=C/C=C(C)/C=C/C1=C(C)CC(O)CC1(C)C</smiles>

$\left(3 R, 6^{\prime} R\right)$-3-Hydroxy-2',3'-didehydro- $\beta, \varepsilon$-carotene [Anhydrolutein II] (6)<smiles>CC1=C(/C=C/C(C)=C/C=C/C(C)=C/C=C/C=C(C)/C=C/C=C(C)/C=C/C2=C(C)CC(O)CC2(C)C)C(C)(C)C=CC1</smiles>

(3R)-3-Hydroxy-3',4'-didehydro- $\beta, \beta$-carotene [3',4'-Anhydrolutein III] (7)<smiles>CC1=CC(O)=CC(C)(C)[C@H]1/C=C/C(C)=C/C=C/C(C)=C/C=C/C=C(C)/C=C/C=C(C)/C=C/C1=C(C)CC(O)CC1(C)C</smiles><smiles>CC1=C(/C=C/C(C)=C/C=C/C(C)=C/C=C/C=C(C)/C=C/C=C(C)/C=C/C2=C(C)C[C@@H](O)CC2(C)C)C(C)(C)C[C@H](O)C1</smiles>

(3R,3'S;meso)-Zeaxanthin (9)

Figure 2. Structures of several metabolites of dietary $\left(3 R, 3^{\prime} R, 6^{\prime} R\right)$-lutein (1) and (3R, $\left.3^{\prime} R\right)$-zeaxanthin (2); 5-9 have been identified in human plasma and breast milk while only 8 and 9 have only been identified in human ocular tissues.

cessible from two consecutive deoxygenation of $\mathbf{1}$ via $\mathbf{3}$ (Fig. 3).

Therefore, several relatively straightforward semisynthetic processes have been developed that transform 1 into 3-10 in excellent yields and high optical purities. These processes provide easy access and alternative routes to optically active carotenoids that are normally prepared by multi-step synthesis.

\section{RESULTS AND DISCUSSION}

To accomplish the synthesis of hydroxycarotenoids, $\left(3 R, 3^{\prime} R, G^{\prime} R\right)$-lutein (1) that is commercially available from saponified extracts of marigold flowers (Tagetes erecta) has been employed as the key starting material. The allylic deoxygenation of $\mathbf{1}$ at the 3 -position under mild reaction conditions to $\mathbf{3}$ was accomplished by a number of reagents under mild conditions in excellent yields (Khachik et al., 2007) (Scheme 1). In another approach, 1 was subjected to ionic hydrogenation with triethylsilane/trif-

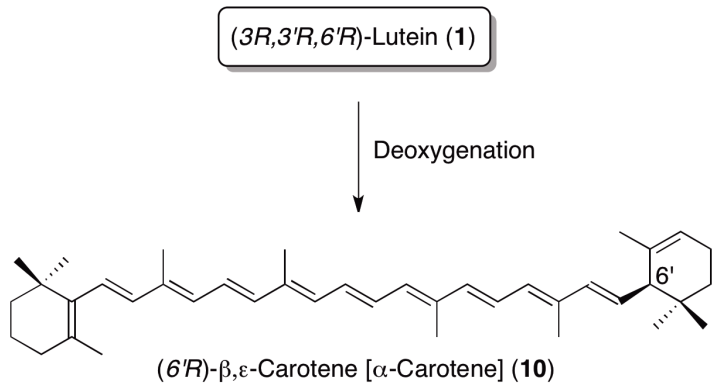

Figure 3. $\left(3 R, 3^{\prime} R, 6^{\prime} R\right)$-lutein (1) as a possible precursor of $\left(6^{\prime} R\right)$-acarotene (10).<smiles>CC1=C[C@H](O)CC(C)(C)[C@H]1/C=C/C(C)=C/C=C/C(C)=C/C=C/C=C(C)/C=C/C=C(C)/C=C/C1=C(C)C[C@@H](O)CC1(C)C</smiles>

$\left(3 R, 3^{\prime} R, 6^{\prime} R\right)$-Lutein (1)
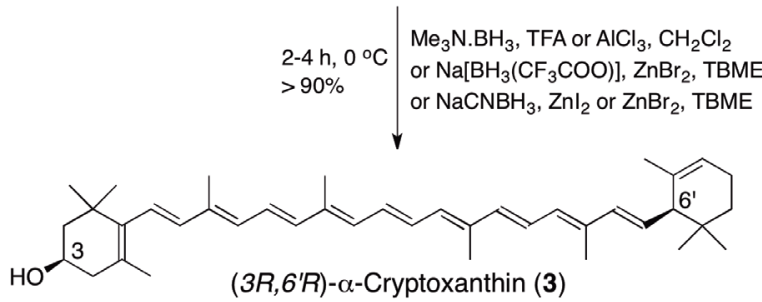

Scheme 1. Partial synthesis of $\left(3 R, 6^{\prime} R\right)$-a-cryptoxanthin (3) from $\left(3 R, 3^{\prime} R, 6^{\prime} R\right)$-lutein (1); TBME: tert-butyl methyl ether (Khachik et al., 2007).

luoroacetic acid $\left(\mathrm{Et}_{3} \mathrm{SiH} / \mathrm{TFA}\right)$ that is a known reagent for the reduction of multiple bonds and deoxygenation of single bonds such as C-OH (Kursanov et al., 1974). This resulted in the formation of a mixture of 3 and 4 as well as a mixture of lutein dehydration products that were identified as $\left(3 R, \sigma^{\prime} R\right)$-3-hydroxy- $3^{\prime}, 4^{\prime}$-didehydro- $\beta, \gamma$ carotene [anhydrolutein I] (5), (3R, $\left.\sigma^{\prime} R\right)$-3-hydroxy- $2^{\prime}, 3^{\prime}-$ didehydro- $\beta, \varepsilon$-carotene [anhydrolutein II] (6), and (3R)-3hydroxy-3',4'-didehydro- $\beta, \beta$-carotene [anhydrolutein III] (7) (Khachik et al., 2007). Carotenoids 5, 6, and 7 are the dehydration products of dietary lutein that have been isolated and characterized in extracts from human plas$\mathrm{ma}$; these carotenoids are presumably formed in human digestive system in the presence of acids (Khachik et al., 1995). It should be noted that 8 is also a precursor of vitamin A2. Following the course of this reaction, it was revealed that 1 was first dehydrated to 5,6 , and 7 and subsequently these carotenoids were in part converted to 3 and 4. Low temperature acid-catalyzed dehydration of lutein has been shown to yield predominantly $\mathbf{5}$ as the

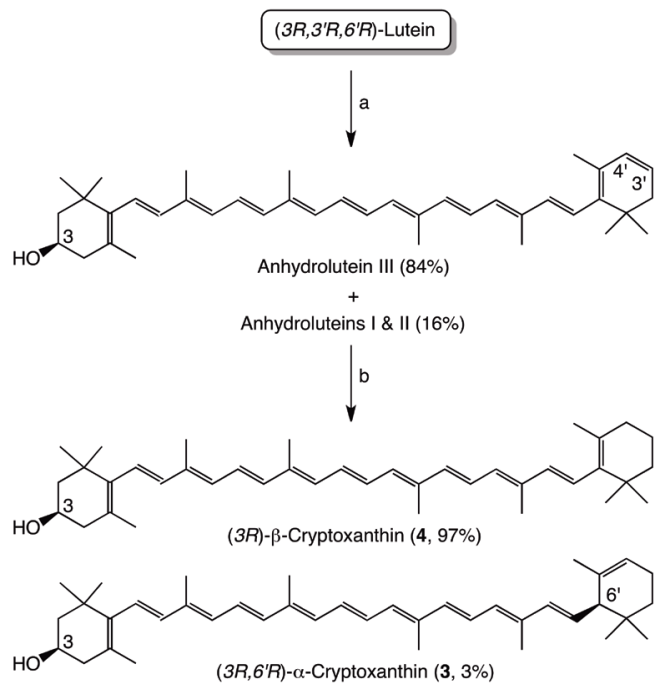

Scheme 2. Two-steps transformation of $\left(3 R, 3^{\prime} R, 6^{\prime} R\right)$-lutein (1) to $\left(3 R, 6^{\prime} R\right)$-a-cryptoxanthin (3) and (3R)- $\beta$-cryptoxanthin (4) via anhydroluteins 5, 6, and 7; step one: dehydration of $1,(\mathrm{a}) \mathrm{HCl}$, $\mathrm{H}_{2} \mathrm{O}$, propanol ( $\left.\mathrm{PrOH}\right), 45-90^{\circ} \mathrm{C}$; step two: regioselective ionic or catalytic hydrogenation of a mixture of 6-8, (b) trifluoroacetic acid $\left(\mathrm{CF}_{3} \mathrm{CO}_{2} \mathrm{H}\right)$, borane-trimethylamine $\left(\mathrm{Me}_{3} \mathrm{~N}_{0} \mathrm{BH}_{3}\right)$, dichloromethane $\left(\mathrm{CH}_{2} \mathrm{Cl}_{2}\right) ; \mathrm{H}_{2} /$ catalyst/ $\mathrm{CH}_{2} \mathrm{Cl}_{2}$ or ethyl acetate (EtOAc); two consecutive crystallization $\left(\mathrm{CH}_{2} \mathrm{Cl}_{2} / \mathrm{EtOH}\right)$ (Khachik et al., 2007). 

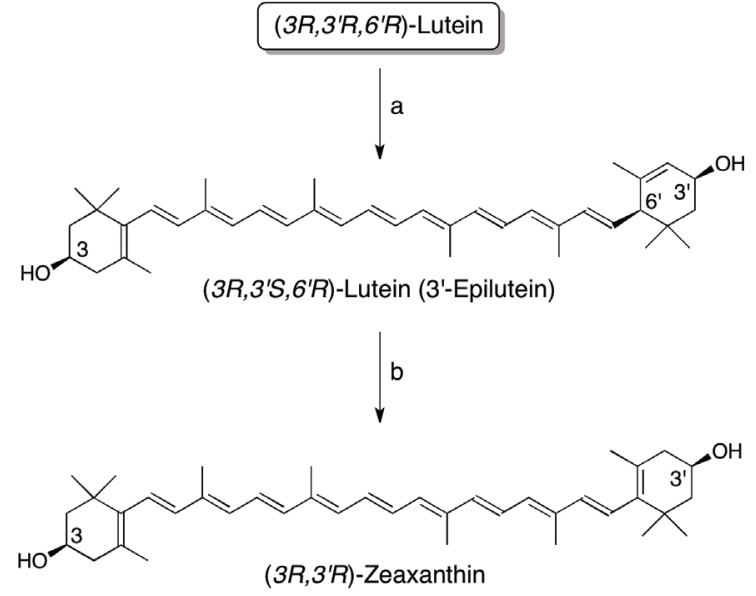

Scheme 3. Partial synthesis of $\left(3 R, 3^{\prime} R\right)$-zeaxanthin (2) from $\left(3 R, 3^{\prime} R, 6^{\prime} R\right)$-lutein (1) via $3^{\prime}$-epilutein (8); a) 1 . $\mathrm{HCl}(5 \%), \mathrm{H}_{2} \mathrm{O}$, tetrahydrofuran (THF), 2. low-temperature crystallization; 2 . basecatalyzed isomerization, $\mathrm{KOH}(9 \mathrm{M})$, phase transfer catalyst, hexane (reflux) (Khachik et al., 2003).

major product and 6 and 7 as the minor products. Because $\mathbf{5}$ and $\mathbf{6}$ appeared to have been converted to $\mathbf{3}$ by ionic hydrogenation, this approach resulted in the formation of a complex mixture of products in which 3 was the major product and 4 the minor product. Because the ionic hydrogenation of 7 was most likely responsible for the formation of 4 , the low yield of this carotenoid appeared to be due to the low yield of its precursor.

Therefore, in an attempt to transform 1 to 4 a twostep process was developed. In the first step, 1 was first dehydrated to a mixture of $\mathbf{5}, \mathbf{6}$, and $\mathbf{7}$ at high temperature to obtain the thermodynamically stable 7 as the major product. This was accomplished in a refluxing solution of 1 in propanol-water $\left(\mathrm{PrOH}-\mathrm{H}_{2} \mathrm{O}\right)$ at $90^{\circ} \mathrm{C}$ in the presence of catalytic amounts of hydrochloric $(\mathrm{HCl})$ or sulfuric acid $\left(\mathrm{H}_{2} \mathrm{SO}_{4}\right)$ in which anhydroluteins $\mathrm{I}(5)$ and anhydrolutein II (6) underwent isomerization to anhydrolutein III (7) within 12-18 h to yield a mixture of anhydroluteins in $85 \%$ yield in which the composition of the mixture was determined by HPLC as 7 (86\%), 6 $(9 \%)$, and $\mathbf{5}(5 \%)$. The ionic hydrogenation of the resulting mixture of anhydroluteins afforded a mixture of 4 $(88 \%)$ and $3(12 \%)$ in yields greater than $80 \%$. Following two consecutive crystallizations, the ratio of 4 to 3 could be improved to 97:3 (Scheme 3) (Khachik et al., 2007).

Another process has also been developed that converts 1 into $\left(3 R, 3^{\prime} R\right)$-zeaxanthin (2) via (3R, 3'S, $6^{\prime} R$ )-lutein (3'-epilutein, 8) as shown in Scheme 3 (Khachik, 2003). This involved epimeriziation of 1 in dilute acidic solution followed by low-temperature crystallization that allowed the separation of $\mathbf{8}$ from unreacted 1 . The base-catalyzed isomerization of $\mathbf{8}$ with $\mathrm{KOH}(9 \mathrm{M})$ in refluxing hexane in the presence of phase transfer catalyst afforded 2 in high yield. This step was carried out similar to the basecatalyzed isomerization of 1 to $\left(3 R, 3^{\prime} S\right.$;meso)-zeaxanthin (9) that was first reported by Bernhard and Giger (1998).

Anhydrolutein III (7) has also been shown to serve as a useful precursor in the synthesis of $\left(3 R, 3^{\prime} R\right)$-zeaxanthin (2) and its meso-isomer (9). Hydroboration of 7 with $\mathrm{BH}_{3}$-THF prepared in situ from $\mathrm{NaNH}_{4} / \mathrm{CH}_{3} \mathrm{I}$ afford a mixture of 2 and 9 that were separated by enzymemediated acylation with lipase PS (Psendomonas cepacia) or lipase AK (Pseudomonas fluorescens) in high diastereomeric ratio $(d r)$ as shown in scheme 4 (Khachik, 2009).
(3R)-3', 4'-Didehydro- $\beta, \beta$-caroten-3-ol (Anhydrolutein III, 7)

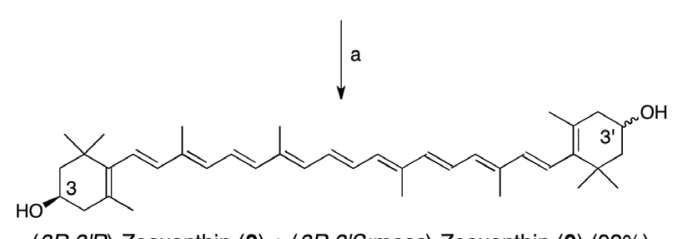

$\left(3 R, 3^{\prime} R\right)$-Zeaxanthin (2) + (3R,3'S;meso)-Zeaxanthin (9) $(92 \%)$

b

(3R,3'R)-Zeaxanthin, $d r$ 96:4

(3R,3'S;meso)-Zeaxanthin, dr 97:3

Scheme 4. Partial synthesis of $\left(3 R, 3^{\prime} R\right)$-zeaxanthin (2) and (3R, 3'S;meso)-zeaxanthin (9) from (3R, $\left.3^{\prime} R, 6^{\prime} R\right)$-lutein $(1)$; a) 1 . $\mathrm{BH}_{3}-\mathrm{THF}, 2$. $\mathrm{NaOH}(3 \mathrm{~N}), \mathrm{H}_{2} \mathrm{O}_{2}(30 \%)$, 3. crystallization; b) 1. lipase PS (Pseudomonas cepacia) or lipase AK (Pseudomonas fluorescens), vinyl acetate, THF, r.t., 2. chromatography (Khachik, 2009).

\section{CONCLUSION}

The semisynthetic approach to optically active hydroxycarotenoids and their metabolites provides an alternative to total synthesis and can minimize the difficulties associated with multistep synthesis and, in addition, affords a much higher yield of the desired product. Commercially available $\left(3 R, 3^{\prime} R, G^{\prime} R\right)$-lutein (1) has been shown to serve as a key starting material in partial synthesis of $\left(3 R, \sigma^{\prime} R\right)-\alpha$-cryptoxanthin (3) and (3R)- $\beta$-cryptoxanthin (4) in two convenient steps via anhydroluteins I - III (5-7) in high yield. In addition, 1 can also be directly converted to $\mathbf{3}$ in a single step in greater than $90 \%$ yield. In another process, 1 has been efficiently converted to $\left(3 R, 3^{\prime} R\right)$-zeaxanthin (2) via $3^{\prime}$-epilutein (8) that is a metabolite of 1 and/or 2 identified in human serum, breast milk, and ocular tissues. In an alternative process 1 has been transformed into a mixture of 2 and (3R,3'S;meso)zeaxanthin (9) that were separated by enzyme-mediated acylation. These methodologies provide an easy access to optically active hydroxycarotenoids that have been shown to exhibit biological activities and enables researchers to further study the bioavailability and efficacy of these carotenoids in the prevention of chronic diseases.

\section{REFERENCES}

Ausich RL, Sanders DJ (1997) Process for the formation, isolation and purification of comestible xanthophyll crystals from plants. Kemin Industries, Inc. U.S. Patent, 5,648,564, July 17.

Bernhard K, Giger A (1998) Process for the manufacturing of zeaxanthin from lutein. US Patent to Hoffmann-La Roche, 5,780,693.

Bernstein PS et al. (2001) Identification and quantitation of carotenoids and their metabolites in the tissues of the human eye. Exper Eye Res 72: 215-223.

Bone RA, Landrum JT, Hime GW, Cains A, Zamor J (1993) Stereochemistry of the human macular carotenoids. Investigative Ophthalmol \& Vis Sci 34: 2033-2040.

Khachik F, Beecher GR, Goli MB, Lusby WR (1991) Separation, identification, and quantification of carotenoids in fruits, vegetables and human plasma by high performance liquid chromatography. Pure \&o Appl Chem 63: 71-80.

Khachik F, Beecher GR, Goli MB, Lusby WR, Smith Jr. JC (1992) Separation and identification of carotenoids and their oxidation products in extracts of human plasma. Anal Chem 64: 2111-2122.

Khachik F (1995) Process for isolation, purification, and recrystallization of lutein from saponified marigolds oleoresin and uses thereof. The Catholic University of America. U.S. Patent, 5,382,714, January 17. 
Khachik F, Englert G, Beecher GR, Smith Jr. JC (1995) Isolation, structural elucidation, and partial synthesis of lutein dehydration products in extracts from human plasma. J Chromatogr Biomed Appl 670: 219-233.

Khachik F, Spangler CJ, Smith Jr. JC, Canfield LM, Pfander H, Steck A (1997a) Identification, quantification, and relative concentrations of carotenoids, and their metabolites in human milk and serum. Anal Chem 69: 1873-1881.

Khachik F, Bernstein P, Garland DL (1997b) Identification of lutein and zeaxanthin oxidation products in human and monkey retinas. $J$ Invest Ophthalmol \& Vis Sci 38: 1802-1811.

Khachik F, Moura FF, Zhao DY, Aebischer CP, Bernstein PS (2002) Transformations of selected carotenoids in plasma, liver, and ocular tissues of humans and in non-primate animal models. I Invest $O p h$ thalmol \& Vis Sci 43: 3383-3392.

Khachik F (2003) An efficient conversion of $\left(3 R, 3^{\prime} R, G^{\prime} R\right)$-lutein to $\left(3 R, 3^{\prime} S, 6^{\prime} R\right)$-lutein $\left(3^{\prime}\right.$-epilutein) and $\left(3 R, 3^{\prime} R\right)$-zeaxanthin. I Nat Prod 66: $67-72$.

Khachik F (2006) Distribution and metabolism of dietary carotenoids in humans as a criterion for development of nutritional supplements. Pure \& Appl Chem 78: 1551-1557.
Khachik F, Chang AN, Gana A, Mazzola E (2007) Partial synthesis of $\left(3 R, \sigma^{\prime} R\right)-\alpha$-cryptoxanthin and (3R)- $\beta$-cryptoxanthin from (3R, 3'R, $\left.\sigma^{\prime} \mathrm{R}\right)-$ lutein. I Nat Prod 70: 220-226.

Khachik F (2009) Process for synthesis of (3R,3'R)-reaxanthin and $\left(3 R, 3^{\prime} S\right.$;meso)-zeaxanthin from $\left(3 R, 3^{\prime} R, 6^{\prime} R\right)$-lutein via $(3 R)-3^{\prime}, 4^{\prime}$-anbydrolutein. US Patent, 12/406,543.

Khachik F, Chang AN (2009) Total synthesis of $\left(3 R, 3^{\prime} R, 6^{\prime} R\right)$-lutein and its stereoisomers. J Org Chem 74: 3875-3885.

Kursanov DN, Parnes ZN, Loim NM (1974) Application of ionic hydrogenation to organic synthesis. Synthesis 633-651.

Morris DL, Kritchevsky SB, Davis CE (1994) Serum carotenoids and coronary heart disease. J Am Med Assoc 272: 1439-1441.

Seddon JM et al. (1994) Dietary carotenoids, vitamin A, C, and E, and advanced age-related macular degeneration. J Am Med Assoc 272: 1413-1420.

Van Poppel G (1993) Carotenoids and Cancer: an update with emphasis on human intervention studies. Europ J Cancer 29A: 1335-1344. 